\title{
IMPLEMENTING CHANGES IN TEACHING EFL THROUGH AUTONOMOUS LEARNING IN NORTH MACEDONIA
}

\begin{abstract}
Autonomous learning is one of the new challenges that can be introduced to students in order to increase their ability and skills for life-long learning. Increasing learner autonomy in education is a complex process which should be introduced in all cycles of education. The study investigates student learner autonomy and their attitudes towards this issue. It further, explores teacher practices and methods used to increase it. The self-assessment survey used with participants contains nine parts and the participants were asked to answer it online. The overall results showed that students choose their own resources including the ones from library, their own learning strategies but strongly believe that teachers should open them new learning possibilities. Teachers, on the other hand, believe that students should become more responsible for their own learning and not rely on teachers all the time.
\end{abstract}

Key words: learner autonomy, University, self-assessment survey, teachers, students

\section{Introduction}

Even though the concept of learner autonomy is experiencing revolutionary growth and development in many educational contexts, this concept has not been much explored in the context of North Macedonia. The notion of "learner autonomy" was first introduced by Henry Holec in 1981 at the Council of Europe. Holec's definition of learner autonomy was "the ability to take charge of one's own learning," noting that this ability "is not inborn but must be acquired either by 'natural' means or (as most often happens) by formal learning, i.e. in a systematic, deliberate way" (Holec 1981, cited in Little 1991). Perhaps Benson and Voller's (1997) idea that educators have moved too quickly from theory to practice requires much more research and work in this direction to make it more effective in different teaching/learning contexts.

\footnotetext{
“South East European University, Iljindenska bb, Tetovo, 1220, North Macedonia; e-mail: b.xhaferi@seeu. edu.mk
} 
The assessment of student autonomy in language learning is very important in education because it can answer many questions related to learning. The students themselves can reflect on their own learning practices and learning strategies they use to accomplish different learning tasks required from them. Tassinary (2012) is of the opinion that crucial issues which characterize Learner Autonomy is understood as observable behaviors and understandable criteria in different learning contexts.

The primary purpose of the study was to identify students' strengths and weaknesses in language learning, and also to raise students' awareness of learner autonomy. The study also seeks to provide some answers on different fields important for LA. Those filed include: Motivating myself; Choosing materials and resources; Cooperating; Structuring knowledge; Planning my learning; Carrying out a task; Monitoring my learning; Evaluating my learning and Working with media.

\section{Literature review}

Since Holec's definition in 1981, many other scholars have provided different ones. Little (1991: 2), for example stated that "Autonomy is essentially a matter of the learner's psychological relation to the process and content of learning." Dickinson (1987: 11) says, "Autonomy is a situation in which the learner is totally responsible for all the decisions concerned with his [or her] learning and the implementation of those decisions." And Benson (1997: 29) states, "Autonomy is a recognition of the rights of learners within educational systems."

In the field of second and foreign language teaching and learning, as the theory and practice of language teaching enters a new century, "the importance of helping students become more autonomous in their learning has become a more prominent theme" (Benson 2000, cited in Dafei 2007: 3). Furthermore, as Benson puts it, "to its critics, autonomy is an idealistic goal and its promotion a distraction of from the real business of teaching and learning languages. To its advocates, autonomy is a precondition for effective learning (Benson 2011: 1).

On the other hand, a psychological definition of learner autonomy involves seeing the concept basically as an ability of the students to take responsibility for their learning, to have their own commitment to the learning content, and to monitor their learning process. The teacher's role is that of a manager, facilitator and agitator for self-dependent learning, rather than an instructor of content knowledge. Voller's (1997: 102) summary of previous literature Benson (2011: 186f.) lists concrete functions and qualities of a teacher distinguishing between "technical" and "psychosocial" support for students. For the former, he lists support for the students' planning and carrying out their language learning (such as the setting of objectives, selection of materials, organization of interactions), their evaluation process (monitoring, peer- 
and self-assessment), and acquisition of learning strategies and learning awareness. By "psycho-social" support he means the facilitator's qualities in general, and both motivational as well as meta-cognitive practices in particular. The teacher's role is generally seen as an important factor for autonomous learning. As a crucial term for successful "teaching of learner autonomy", it is stated in several publications (cf. e.g. Dam 2003) that teachers have to believe in their students' ability to manage their own studies and as a consequence they also need to relinquish responsibility.

Although we find some consensus among researchers on the understanding of learner autonomy, Borg and Al-Busaidi (2012: 5) note that the same is not the case with in-service teachers' beliefs about learner autonomy. Little research has been conducted on this aspect and there is some evidence that older misconceptions mentioned by Little (see above) might persist among teachers (ibid.). In their reference of older studies, they note the evidence that teachers generally have a positive attitude to theoretical aspects of learner autonomy, such as situational classroom management and learning strategies, but utter doubts when it comes to practical realization.

Learner Autonomy is one of the most important elements in learning a foreign language. Additionally, many EFL learners acquire different beliefs, attitudes, and motivations, or they do not want to take responsibility for their own learning. Teachers should deal with these issues by engaging students with effective activities, or find successful ways in promoting learner autonomy. Cotterall and Crabbe (2008: 126) emphasize that "teachers should create a database of learner experiences about their learning in order to familiarize themselves with how their students learn and difficulties they encounter while learning." Investigating learners' difficulties and taking into account the learners' needs and preferences will help teachers manage the class effectively. Furthermore, the required information that teachers get from the students regarding their attitude will help teachers find more useful and appropriate techniques in promoting learner autonomy.

\section{Research design and methodology}

The main purpose of the study was to focus on learners' experiences with learner autonomy and reflect on those experiences. The survey was conducted in Fall 2018/2019 and it helped us to find some answers to the main issues related to LA in language learning at SEEU. The study included both male and female students, and the instrument used was the self-assessment student questionnaire.

\subsection{Participants}

The participants of the study were EFL students studying at the South East European University. The age of the participants ranged from 19 to 23. They belong 
to different ethnic groups such as: Albanians, Macedonians, and the Turkish. The participants included both males and females. The total number of participants involved in the study was 108. The participants were all majoring in English or German.

\subsection{Instruments}

The students were surveyed using a student questionnaire (see Appendix 1). The questionnaire is a modified version of the questionnaire developed by Tassinary in 2010. It contained 8 topics, and the aim was to identify student knowledge of LA as well as to measure the level of autonomy they possess for language learning. The topics included are: Motivation, Selecting materials and resources, Cooperating, Structuring knowledge, Planning learning, Carrying out, Monitoring learning, Evaluating learning and Working with Media. The LIME survey was used for the purpose of the study and it was translated into Albanian as well.

\section{Results}

The self-assessment survey was modified from Tassinari's Dynamic Model (2010), which focuses on different dimensions and components. Topic one, Motivating myself, aimed to investigate the students' level of motivation to study. A six-item Likert scale was used to measure participants' responses

\begin{tabular}{|l|c|c|c|c|c|c|}
\hline & never & rarely & sometimes & often & always & $\begin{array}{c}\text { I can't } \\
\text { answer }\end{array}$ \\
\hline 1. I am motivated to study. & 0 & 3 & 21 & 41 & 42 & 1 \\
\hline $\begin{array}{l}\text { 2. I motivate myself } \\
\text { to study by choosing for } \\
\text { example materials that interest } \\
\text { me. }\end{array}$ & 1 & 2 & 15 & 41 & 49 & 0 \\
\hline $\begin{array}{l}\text { 3. I am aware of my } \\
\text { motivation to learn and can } \\
\text { reflect on it. }\end{array}$ & 0 & 9 & 19 & 29 & 50 & 1 \\
\hline $\begin{array}{l}\text { 4. I remotivate myself } \\
\text { again when my initial } \\
\text { motivation } \\
\text { is wearing thin. }\end{array}$ & 3 & 6 & 37 & 23 & 39 & 0 \\
\hline $\begin{array}{l}\text { 5. I organize my learning } \\
\text { independently from the } \\
\text { teachers. }\end{array}$ & 2 & 5 & 26 & 37 & 37 & 1 \\
\hline
\end{tabular}

Table 1. Motivating myself 
SEEU participants seem to be motivated to study and they also use their own study materials. There is a will to reflect on their motivation and more than half of them organize their learning independently from the teacher.

\begin{tabular}{|l|c|c|c|c|c|c|}
\hline & never & rarely & $\begin{array}{c}\text { sometimes } \\
\text { (A03) }\end{array}$ & $\begin{array}{c}\text { often } \\
\text { (A04) }\end{array}$ & $\begin{array}{c}\text { always } \\
\text { (A05) }\end{array}$ & $\begin{array}{c}\text { I can't } \\
\text { answer }\end{array}$ \\
\hline $\begin{array}{l}\text { 1. I choose suitable } \\
\text { materials and resources } \\
\text { for myself. }\end{array}$ & 2 & 3 & 28 & 30 & 44 & 1 \\
\hline $\begin{array}{l}\text { 2. I try out new materials } \\
\text { and resources. }\end{array}$ & 0 & 13 & 36 & 34 & 24 & 1 \\
\hline $\begin{array}{l}\text { 3. I choose suitable } \\
\text { methods and strategies. }\end{array}$ & 2 & 8 & 15 & 37 & 46 & 0 \\
\hline $\begin{array}{l}\text { 4. I try out new methods } \\
\text { and strategies. }\end{array}$ & 1 & 13 & 43 & 31 & 20 & 0 \\
\hline $\begin{array}{l}\text { 5. I use media from the } \\
\text { library. }\end{array}$ & 9 & 25 & 30 & 30 & 14 & 0 \\
\hline
\end{tabular}

Table 2. Choosing materials and resources

The results of part two, show that students choose their own resources including the ones from the library. In addition, students choose suitable methods and strategies, which means that they are aware of the importance.

\begin{tabular}{|l|c|c|c|c|c|c|}
\hline & never & rarely & sometimes & often & always & $\begin{array}{c}\text { I can't } \\
\text { answer }\end{array}$ \\
\hline $\begin{array}{l}\text { 1. I study with other } \\
\text { classmates. }\end{array}$ & 10 & 31 & 33 & 23 & 11 & 0 \\
\hline $\begin{array}{l}\text { 2. I learn from experts } \\
\text { (lecturers, teachers, coaches, } \\
\text { native speakers, etc.). }\end{array}$ & 5 & 7 & 23 & 36 & 36 & 1 \\
\hline $\begin{array}{l}\text { 3. I work in groups to } \\
\text { complete tasks. }\end{array}$ & 10 & 21 & 39 & 29 & 9 & 0 \\
\hline $\begin{array}{l}\text { 4. I decide when I study with } \\
\text { others in order to structure my } \\
\text { learning better. }\end{array}$ & 9 & 20 & 37 & 16 & 21 & 5 \\
\hline
\end{tabular}

Table 3. Cooperation 
It seems that students learn a lot from experts and it seems that there are still some elements of traditional teaching left. The majority of the students prefer to work in groups; therefore, teachers should strengthen group work in their classes.

\begin{tabular}{|l|c|c|c|c|c|c|}
\hline & never & rarely & sometimes & often & always & $\begin{array}{c}\text { I can't } \\
\text { answer }\end{array}$ \\
\hline $\begin{array}{l}\text { 1. I visualize new content } \\
\text { (mindmap, drawing pictures, } \\
\text { etc.). }\end{array}$ & 7 & 17 & 42 & 28 & 13 & 1 \\
\hline $\begin{array}{l}\text { 2. I connect newly learnt } \\
\text { content to what I already know. }\end{array}$ & 0 & 8 & 30 & 35 & 32 & 3 \\
\hline $\begin{array}{l}\text { 3. I try to find connections to } \\
\text { other subjects or courses. }\end{array}$ & 3 & 17 & 40 & 29 & 18 & 1 \\
\hline $\begin{array}{l}\text { 4. I look for relevant links } \\
\text { to my everyday life or to my } \\
\text { teaching practice. }\end{array}$ & 2 & 13 & 26 & 42 & 25 & 0 \\
\hline $\begin{array}{l}\text { 5. I think of practical } \\
\text { applications of new concepts. }\end{array}$ & 0 & 13 & 40 & 34 & 18 & 3 \\
\hline $\begin{array}{l}\text { 6. I compare advantages and } \\
\text { disadvantages of various } \\
\text { theoretical concepts. }\end{array}$ & 3 & 9 & 49 & 28 & 17 & 2 \\
\hline $\begin{array}{l}\text { 7. I use the learned information } \\
\text { as a starting point for the } \\
\text { development of my own ideas. }\end{array}$ & 0 & 7 & 27 & 33 & 39 & 2 \\
\hline
\end{tabular}

Table 4. Structuring knowledge

Regarding topic 4, structuring knowledge, it seems that students can use information learned as a starting point for developing their own ideas.

\begin{tabular}{|l|c|c|c|c|c|c|}
\hline & never & rarely & sometimes & often & always & $\begin{array}{c}\text { I can't } \\
\text { answer }\end{array}$ \\
\hline $\begin{array}{l}\text { 1. I analyze my own learning } \\
\text { needs. }\end{array}$ & 0 & 0 & 17 & 36 & 54 & 1 \\
\hline $\begin{array}{l}\text { 2. I know what I need to } \\
\text { complete a task. }\end{array}$ & 1 & 4 & 16 & 38 & 49 & 0 \\
\hline $\begin{array}{l}\text { 3. I put together a learning } \\
\text { plan. }\end{array}$ & 4 & 9 & 22 & 25 & 48 & 0 \\
\hline
\end{tabular}




\begin{tabular}{|l|c|c|c|c|c|c|}
\hline $\begin{array}{l}\text { 4. I set myself goals (about } \\
\text { what I want to learn, for } \\
\text { example being able to start a } \\
\text { conversation, to keep it going } \\
\text { and to finish it). }\end{array}$ & 2 & 4 & 17 & 27 & 57 & 1 \\
\hline 5. I plan the time for studying. & 3 & 10 & 12 & 32 & 51 & 0 \\
\hline 6. I plan where to study. & 11 & 16 & 16 & 23 & 42 & 0 \\
\hline
\end{tabular}

Table 5. Planning learning

In terms of planning learning, students seem to set a goal for themselves, analyze their own learning needs and plan the time for studying. This element is very useful which can encourage autonomous learning in students.

\begin{tabular}{|l|c|c|c|c|c|c|}
\hline & never & rarely & sometimes & often & always & $\begin{array}{c}\text { I can't } \\
\text { answer }\end{array}$ \\
\hline $\begin{array}{l}\text { XF1 1. The set-up of my work } \\
\text { space supports my learning in } \\
\text { an ideal way. }\end{array}$ & 3 & 11 & 27 & 39 & 23 & 5 \\
\hline $\begin{array}{l}\text { XF1 2. I carry out my time } \\
\text { plan. }\end{array}$ & 5 & 14 & 28 & 32 & 28 & 1 \\
\hline $\begin{array}{l}\text { XF1 3. I carry out my learning } \\
\text { plan. }\end{array}$ & 6 & 9 & 23 & 32 & 37 & 1 \\
\hline $\begin{array}{l}\text { XF1 4. I achieve my learning } \\
\text { aims which I have set myself. }\end{array}$ & 0 & 6 & 14 & 46 & 40 & 2 \\
\hline XF1 5. I set myself a task. & 2 & 2 & 31 & 34 & 37 & 2 \\
\hline
\end{tabular}

Table 6. Carrying out learning

The result for this topic showed that the majority of the students are autonomous enough to set and achieve their learning goals. It was also reported that the students are able to carry out their learning plan and to set a task for themselves. 
Brikena Xhaferi

\begin{tabular}{|l|c|c|c|c|c|c|}
\hline & never & rarely & sometime & often & always & $\begin{array}{c}\text { I can't } \\
\text { answer }\end{array}$ \\
\hline $\begin{array}{l}\text { 1. I monitor and reflect on my } \\
\text { own learning (for example by } \\
\text { keeping a learning diary). }\end{array}$ & 9 & 19 & 40 & 17 & 21 & 2 \\
\hline $\begin{array}{l}\text { 2. I recognize my strengths and } \\
\text { weaknesses as a learner. }\end{array}$ & 0 & 2 & 12 & 27 & 66 & 1 \\
\hline $\begin{array}{l}\text { 2a. I reflect on my strengths } \\
\text { and weaknesses in learning. }\end{array}$ & 0 & 7 & 24 & 32 & 43 & 2 \\
\hline $\begin{array}{l}\text { 3. I recognize what prevents } \\
\text { me from completing a task. }\end{array}$ & 0 & 4 & 26 & 33 & 43 & 2 \\
\hline $\begin{array}{l}\text { 4. I reflect on methods and } \\
\text { strategies which I have } \\
\text { employed. }\end{array}$ & 0 & 6 & 35 & 27 & 36 & 4 \\
\hline $\begin{array}{l}\text { 5. I reflect on materials } \\
\text { and resources which I have } \\
\text { employed. }\end{array}$ & 1 & 9 & 28 & 36 & 30 & 4 \\
\hline
\end{tabular}

Table 7. Monitoring my own learning

Regarding topic 7, students have very strong reflection skills and they can easily recognize their strengths and weaknesses. This is probably due to the fact that learners of SEEU write reflection papers for some courses, and are therefore trained to reflect on their own learning.

\begin{tabular}{|l|c|c|c|c|c|c|}
\hline & never & rarely & sometimes & often & always & $\begin{array}{c}\text { I can't } \\
\text { answer }\end{array}$ \\
\hline $\begin{array}{l}\text { 1. I evaluate my own } \\
\text { language competences/ } \\
\text { competences in the different } \\
\text { subjects. }\end{array}$ & 4 & 8 & 22 & 38 & 36 & 0 \\
\hline $\begin{array}{l}\text { 2. I evaluate my own } \\
\text { language competences/ } \\
\text { competences in the different } \\
\text { subjects. }\end{array}$ & 4 & 6 & 25 & 38 & 34 & 1 \\
\hline
\end{tabular}




\begin{tabular}{|l|c|c|c|c|c|c|}
\hline $\begin{array}{l}\text { 3. I evaluate learning } \\
\text { methods and strategies. }\end{array}$ & 5 & 6 & 25 & 46 & 25 & 1 \\
\hline $\begin{array}{l}\text { 4. I evaluate my learning } \\
\text { (for example if I achieved } \\
\text { my goals). }\end{array}$ & 2 & 4 & 24 & 36 & 41 & 1 \\
\hline
\end{tabular}

Table 8. Evaluation learning results

Students can evaluate their learning whether the goals were achieved or not. On the other hand, some students are able to evaluate their competencies in different subject but they should still work on this.

\begin{tabular}{|l|c|c|c|c|c|c|}
\hline & never & rarely & sometimes & often & always & $\begin{array}{c}\text { I can't } \\
\text { answer }\end{array}$ \\
\hline $\begin{array}{l}\text { 1. I accomplish out-of- } \\
\text { class tasks with the use of } \\
\text { computer. }\end{array}$ & 4 & 5 & 23 & 39 & 37 & 0 \\
\hline $\begin{array}{l}\text { 2. I use technology when I } \\
\text { study. }\end{array}$ & 0 & 7 & 20 & 34 & 47 & 0 \\
\hline $\begin{array}{l}\text { 3. I share information across } \\
\text { the internet with my peers. }\end{array}$ & 3 & 19 & 30 & 39 & 16 & 1 \\
\hline $\begin{array}{l}\text { 4. I download documents } \\
\text { from the internet. }\end{array}$ & 0 & 9 & 22 & 44 & 33 & 0 \\
\hline $\begin{array}{l}\text { 5. I create a digital product to } \\
\text { promote lifelong learning. }\end{array}$ & 19 & 20 & 32 & 22 & 8 & 7 \\
\hline $\begin{array}{l}\text { 6. I do the required online } \\
\text { homework (for example } \\
\text { viewing online lecture; solve } \\
\text { online questions; etc.). }\end{array}$ & 3 & 5 & 19 & 25 & 55 & 1 \\
\hline
\end{tabular}

Table 9. Working with media

Based on topic 9 results, working with Media, more than half of the students do the online tasks required from the University. Students use technology while learning. A very low number of students create a digital product to promote life-long learning.

\section{Conclusion}

Investigating students' level of learner autonomy in a context where students were educated in a learner-centered classroom is very important, because learners' 
reflection on their own learning shapes our success in life, and determines our future path. In fact, the concept of learner autonomy is rather new in North Macedonia because language teachers themselves are not autonomous and they should recognize its' importance. Generally, the results showed that SEEU students bring a fair amount of autonomy to the classroom; nevertheless, it is very important to teach our students how to learn independently and provide them with the necessary knowledge and awareness at the beginning of their studies. An additional crucial aspect of an autonomous classroom is how the teachers perceive their own role. Having this in mind, the teachers should reconsider their role in promoting learner autonomy and teach their learners how to learn.

According to the results obtained from the student survey, students are good in reflecting on their own learning, recognizing both their strengths and weaknesses. Around half of the total number of the participants can choose their own learning materials and use their own strategies for learning new material. Definitely the most surprising results were related to planning learning, where students set their learning goals in terms of what they want to learn and they analyze their own learning needs; therefore, teachers should offer students a chance to openly discuss this with them. Also, almost half of the total number of the participants reported that they do the required online homework, e.g. viewing online lecture, solve online questions, etc. This is a requirement at SEEU because the University uses Google classroom software as a platform to support student learning. Through this platform, students are also required to evaluate teacher performance at the end of the course and get $5 \%$ of the grade. However, only a few of them (8 students) create a digital product to promote lifelong learning.

It can be concluded that the main relevance of the results of the study is the importance of taking into consideration the level of students' autonomy when preparing the course programs. Consequently, if we as teachers aim to increase learnercenteredness, then the curriculum of the study should be constructed with the learner as its central focus.

The main study recommendation is a Module on Learner Autonomy to be included in the Program of Faculty of Languages, Cultures and Communication, because the students can take part in planning the course topics and selecting the content. Students and teachers can discuss the development of a teaching strategy, how to learn/teach, and assessment methods. Students should create their own goals and should be given a chance to reflect on their strengths and weaknesses about language learning. Also, they should be offered a strategy training where they can experiment with new ones. Finally, we should organize workshops where teachers can exchange ideas on how they implement principles of learner autonomy with their students. In the end, we hope that the findings of this paper are of interest to language teachers and students, as well as curriculum designers who plan to include LA in their curricula. 


\section{References}

Balçıkanlı, C. (2010). Learner Autonomy in Language Learning. Student Teachers' Beliefs. Australian Journal of Teacher Education, 35.1, 90-103.

Benson, P. (1997). The philosophy and politics of learner autonomy. In: Lamb, T. and H. Reinders (eds.), Autonomy and Independence in Language Learning. Hong Kong: Hong Kong University Press, 27-34.

Benson, P. (2001). Teaching and Researching Autonomy in Language Learning. London: Longman.

Benson, P. (2007). Learner Autonomy: Teacher and learner perspectives. Dublin: Authentik.

Benson, P. (2008). Teachers' and learners' perspectives on autonomy. In: T. Lamb and H. Reinders (eds.), Learner and Teacher autonomy. Concepts, Realities, and Responses. Amsterdam/Philadelphia: John Benjamins, 15-32.

Benson, P. (2011). Teaching and Researching Autonomy. $2^{\text {nd }}$ edition. Harlow: Longman. Borg, S. and S. Al-Busaidi (2012). Learner Autonomy: English Language Teachers' Beliefs and Practices. ELT Research Paper 12-07. British Council. (8 August 2018)<http://simon-borg.co.uk/wp-content/uploads/2012/12/ELTRP-ReportBorg-Busaidil.pdf $>$.

Dam, L. (2003). Developing learner autonomy: the teacher's responsibility. In: D. Little, J. D. Ridley \& E. Ushioda (eds.), Learner Autonomy in the Foreign Language Classroom: Teacher, Learner, Curriculum and Assessment, Dublin: Authentik, 135-146.

Dafei, D. (2007). An Exploration of the Relationship Between Learner Autonomy and English Proficiency. Asian EFL Journal: Teaching Articles, 1-23.

Dickinson, L. (1987). Self-instruction in language learning. Cambridge: Cambridge University Press.

Dimitrios, T. (2000). What is Learner Autonomy and How Can it be Fostered? Internet TESL Journal, VI, 11. (September 10, 2018) <http://iteslj.org/Articles/ Thanasoulas-Autonomy.htm>.

Ellis, G. and B. Sinclair (1989). Learning to learn English: A course in learner training. Cambridge: Cambridge University Press.

Everhard, C. J. (2018). Investigating the True Colors of Autonomy in Language Learning. (24 September 2019) <https://www.candlinandmynard.com/ uploads/1/2/5/0/12502105/everhard_chapter.pdf $>$.

Holec, H. (1981). Autonomy and foreign language learning. Oxford: Pergamon.

Little, D. (1991). Learner Autonomy: Definitions, Issues and Problems. Dublin: Authentik. 
Littlejohn, A. (1985). Learner choice in language study. ELT Journal, 39(4), 253-261. Liu, Y. (2012). A Study on Learners' Beliefs about Learner Autonomy in English Language Learning. (10 August 2018) <http://link.springer.com/chapter/10. 1007\%2F978-3-642-24775-0_113>.

Tassinari, M. G. (2012). Evaluating learner autonomy: A dynamic model with descriptors. Studies in Self-Access Learning Journal, 3(1), 24-40.

Smith, R. C. (2003). Pedagogy for Autonomy as (Becoming-)Appropriate Methodology. In: D. Palfreyman and R. Smith (eds.), Learner Autonomy Across Cultures: Language Education Perspectives, Basingstoke: Palgrave, 129-146.

Voller, P. (1997). Does the teacher have a role in autonomous learning? In: P. Benson and P. Voller (eds.), Autonomy and Independence in Language Learning, London: Longman, 98-113. 